\title{
BACTERICIDAL ACTIVITY OF SERUM FOR KLEBSIELLA RHINOSCLEROMATIS: STUDIES ON SERUM FROM A PATIENT WITH RHINOSCLEROMA AND SERA DEFICIENT IN ANTIBODY OR COMPLEMENT
}

\author{
M. E. North, C. A. Newton, D. J. M. Wright* and A. D. B. Webster \\ Division of Immunological Medicine, Clinical Research Centre, Harrow, Middlesex HAl 3 UJ \\ and ${ }^{*}$ Dept. of Medical Microbiology, Charing Cross Hospital Medical School, Fulham, London \\ W6 $8 R P$
}

\begin{abstract}
SUmmary. The in-vitro bactericidal effect of serum for Klebsiella rhinoscleromatis was tested. Experiments with C2-deficient and hypogammaglobulinaemic human sera suggested that killing depended on activation of the classical complement pathway, although the alternative pathway probably amplified the effect. Serum from a patient with active rhinoscleroma, and another cured of the disease, showed normal killing.
\end{abstract}

\section{INTRODUCTION}

Rhinoscleroma is a granulomatous condition of the nasopharynx caused by chronic infection with Klebsiella rhinoscleromatis. The disease carries a high morbidity and is endemic in some parts of the world such as San Salvador and Egypt. There are no obvious climatic or genetic factors that predispose to the disease although some patients with it have particularly poor personal hygiene (Muzyka and Gubina, 1972).

Krasilnikov, Izraitel and Shimanovich (1974) have shown that the serum from some patients with active rhinoscleroma had poor in-vitro bactericidal activity against $K$. rhinoscleromatis. We have therefore investigated several factors in normal serum that might be involved in the killing of the organism and have also tested whether there were significant abnormalities in the serum of a patient with rhinoscleroma.

\section{MATERIALS AND METHODS}

\section{Subjects}

Serum was obtained from: patient no. 1 with active rhinoscleroma; patient no. 2, cured of rhinoscleroma a year previously; three patients with adult-onset hypogammaglobulinaemiatwo of these had unrecordable levels of serum immunoglobulin (IgG $<50$, IgA and $\operatorname{IgM}<5$ $\mathrm{mg} / 100 \mathrm{ml}$ ) and the other was treated with injections of gammaglobulin and had a serum IgG of $270 \mathrm{mg} / 100 \mathrm{ml}$ but unrecordable IgA and IgM; a patient with homozygous $\mathrm{C} 2$ deficiency. Serum was also obtained from healthy laboratory staff. In all cases, the serum was separated within 30 min of venesection and then stored at $-70^{\circ} \mathrm{C}$.

\section{Bactericidal tests}

Isotope-release method. K. rhinoscleromatis was isolated from the nose of patient no. 1 with rhinoscleroma and maintained on Columbia Blood Agar (Oxoid) slopes at $4^{\circ} \mathrm{C}$. The bacteria were incubated for $18 \mathrm{~h}$ at $37^{\circ} \mathrm{C}$ in Nutrient Broth (Oxoid) containing uniformly labelled ${ }^{14} \mathrm{C}$ D-glucose of specific activity $300 \mathrm{mCi} / \mathrm{mmol}$ (Radiochemical Centre, Amersham, Bucks) $1 \mu \mathrm{Ci} / \mathrm{ml}$. The bacteria were harvested by centrifugation at $c .1000 \mathrm{~g}$ for $10 \mathrm{~min}$ and washed 
three times in phosphate-buffered saline (PBS). The concentration of the suspension was adjusted to give an optical density of 0.06 at $540 \mathrm{~nm}$ when read against distilled water. This suspension contained approximately $10000 \mathrm{cpm} / 100 \mu \mathrm{l}$.

Serum was diluted in PBS to the required concentration to give a final test volume of $1 \mathrm{ml}$. Tubes were pre-incubated at $37^{\circ} \mathrm{C}$ in a water bath for $5 \mathrm{~min}$. The test was initiated by the addition of $100 \mu \mathrm{l}$ of the ${ }^{14} \mathrm{C}$-labelled bacterial suspension and terminated by placing the tubes in ice. The samples were centrifuged at c. $2000 \mathrm{~g}$ at $4^{\circ} \mathrm{C}$ for $15 \mathrm{~min} ; 500 \mu \mathrm{l}$ of the supernate were removed and the radioactivity was measured in $5 \mathrm{ml}$ of Triton X-100-toluene scintillation fluid, $1: 2(\mathrm{v} / \mathrm{v})$. A control sample of the bacterial suspension in PBS was included in each experiment to give a background release of isotope with time. The value from the control sample was subtracted from the experimental cpm obtained in the presence of serum. Results were expressed as a percentage of the total cpm added.

Plating technique. K. rhinoscleromatis was seeded into $10 \mathrm{ml}$ of Nutrient Broth (Oxoid) and cultured at $37^{\circ} \mathrm{C}$ for $18 \mathrm{~h}$. The bacteria were harvested by centrifugation at $c .1000 \mathrm{~g}$ for $10 \mathrm{~min}$, removing the supernate and resuspending in $5 \mathrm{ml}$ of tissue-culture medium. The bacteria were counted, and the count was adjusted to $5 \times 10^{7}$ organisms $/ \mathrm{ml} \mathrm{immediately} \mathrm{before} \mathrm{use.} \mathrm{Duplicate}$ tubes were set up. To each tube was added $0.1 \mathrm{ml}$ of bacterial suspension, $0.1 \mathrm{ml}$ of serum and $0.8 \mathrm{ml}$ of culture medium. The cultures were then incubated for $1 \mathrm{~h}$ at $37^{\circ} \mathrm{C}$. A $25-\mu \mathrm{l}$ portion of the culture was then removed and added to ice-cold PBS to make 1 in 200 and 1 in 2000 dilutions. Duplicate $25-\mu$ l portions of these two dilutions were spread on nutrient agar and the colonies were counted after overnight incubation at room temperature.

\section{RESULTS}

Fig. 1 shows the rate of release of ${ }^{14} \mathrm{C}$ from $\mathrm{K}$. rhinoscleromatis by $10 \%$ serum from four normal subjects; $70 \%$ of the isotope was released by $60 \mathrm{~min}$. Fig. 1 also shows that the serum

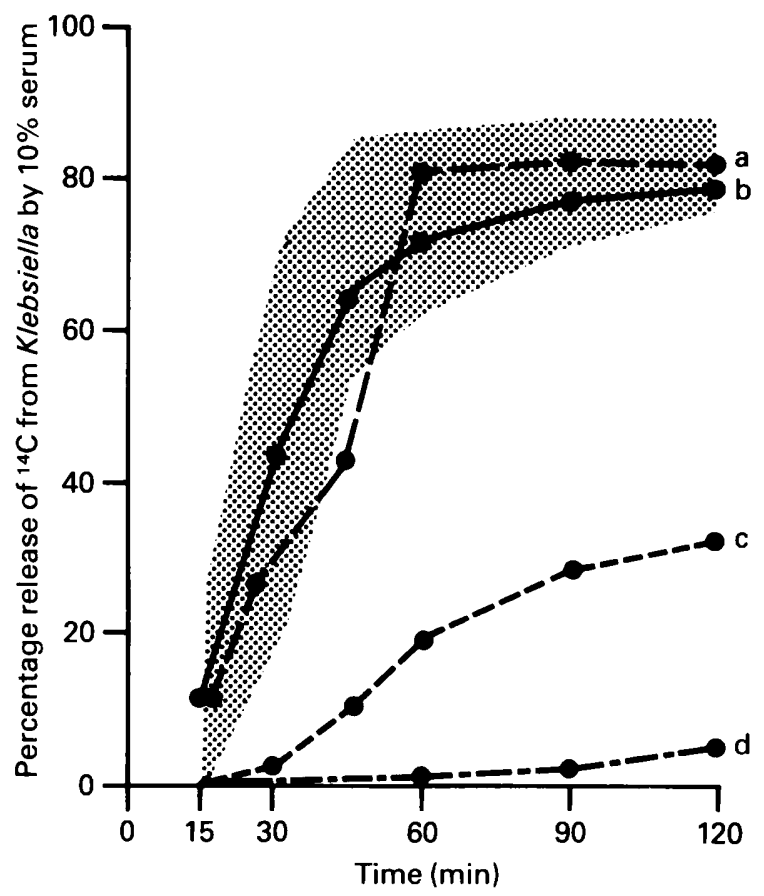

FIG. 1.-Rate of isotope release with $10 \%$ serum. Serum from: a = patient (no. 1) with active rhinoscleroma $\mathrm{b}=$ mean values from four sera from healthy controls; the shaded area indicates the range of results; $\mathrm{c}=$ patient with primary hypogammaglobulinaemia treated with gammaglobulin; $\mathrm{d}=$ untreated patient with primary hypogammaglobulinaemia. 


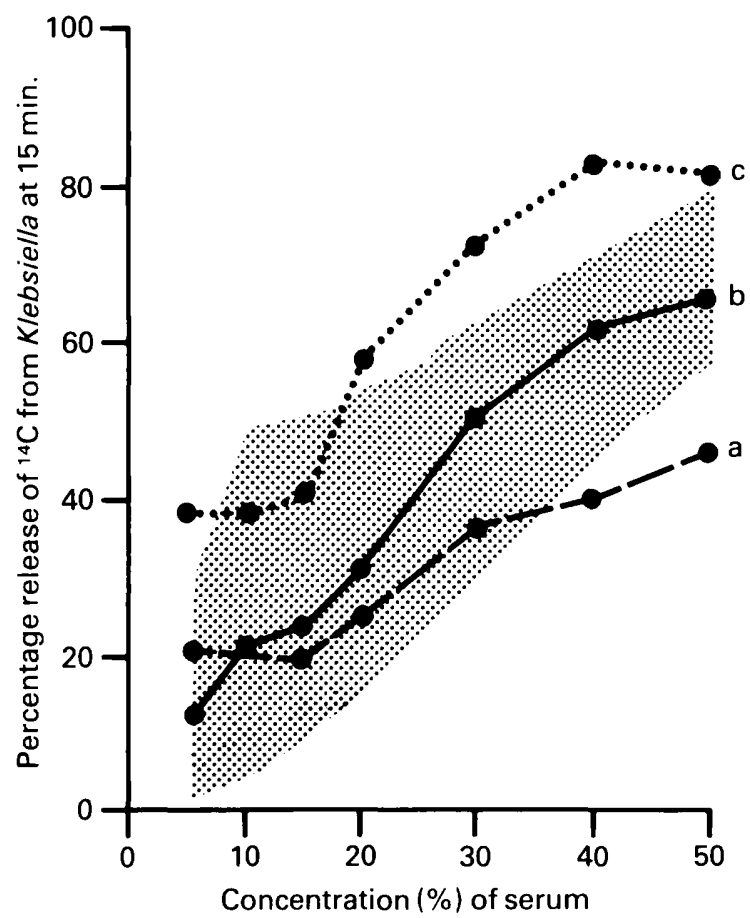

FIG. 2.-Isotope release with increasing concentrations of serum: a=patient (no. 1) with active rhinoscleroma; $b=$ mean values from sera from 13 healthy controls; the shaded area indicates range of results; $\mathrm{c}=$ serum from patient no. 2 cured of rhinoscleroma.

from patient no. 1 with active rhinoscleroma behaved normally. In contrast, sera from the patients with primary hypogammaglobulinaemia released isotope much more slowly.

The fig. 2 shows the ${ }^{14} \mathrm{C}$ release by increasing concentrations of serum from normal subjects and patients after incubation for $15 \mathrm{~min}$. In 13 normal subjects, $50 \%$ (mean of range $30-60 \%$ ) release of ${ }^{14} \mathrm{C}$ was achieved with $30 \%$ serum. The serum of a patient cured of rhinoscleroma 1 year earlier showed greater release than the normal range for concentrations of serum over $20 \%$. The serum from patient no. 1 with active rhinoscleroma showed normal release up to $30 \%$ serum, although with higher concentrations the release was a little below the normal range.

Fig. 3 shows the effect on normal and hypogammaglobulinaemic serum of inhibiting factor $B$ of the alternative complement pathway by heating at $50^{\circ} \mathrm{C}$ for $20 \mathrm{~min}$ (Martin and Lachmann, 1977). However, treating serum in this way also inactivated most of the C2 present and probably much of the $\mathrm{Cl}$. Patients with primary hypogammaglobulinaemia have low serum $\mathrm{Cl}$ levels so there is likely to be very little $\mathrm{Cl}$ activity left after heating. It is therefore difficult to interpret the experiments with hypogammaglobulinaemic serum although the shape of the response curve (fig. 3) suggests that the alternative pathway amplifies the release of isotope.

Fig. 4 shows the results of a bactericidal assay by the plating technique in the presence of serum from a normal subject and from patient no. 1. There was almost complete killing of the organisms by $10 \%(\mathrm{v} / \mathrm{v})$ patient serum at $30 \mathrm{~min}$. Heating normal serum at $56^{\circ} \mathrm{C}$ for $30 \mathrm{~min}$ abolished bactericidal activity. Normal bactericidal activity was also shown by the serum from patient no. 2 who had previously been cured of rhinoscleroma. Serum from normal subjects killed virtually all the organisms in the assay after a 30 -min incubation when diluted down to $5 \%$.

\section{DISCUSSION}

We have shown that serum from normal subjects and patients with active or inactive rhinoscleroma are bactericidal for $K$. rhinoscleromatis. The killing is complement dependent 


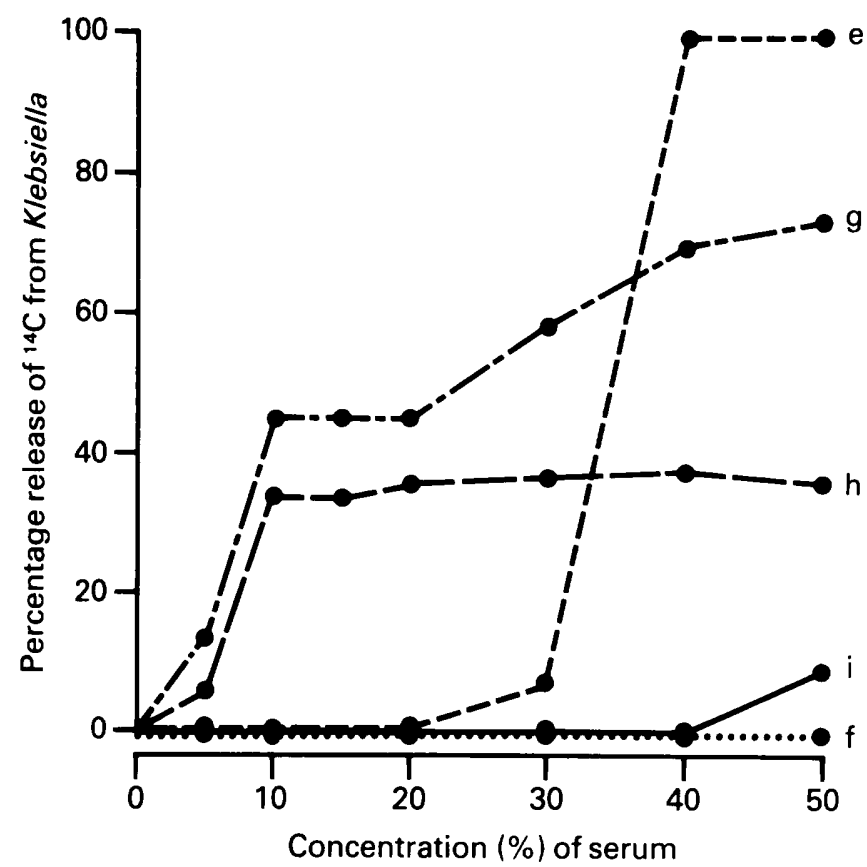

FIG. 3.-Isotope release with increasing concentrations of C2-deficient, hypogammaglobulinaemic and normal sera. Serum from: $\mathrm{e}=$ patient with untreated hypogammaglobulinaemia; $\mathrm{f}=$ same as (e) but heated at $50^{\circ} \mathrm{C}$ for $20 \mathrm{~min} ; \mathrm{g}=$ normal subject; $\mathrm{h}=$ same as $(\mathrm{g})$ but heated at $50^{\circ} \mathrm{C}$ for $20 \mathrm{~min}$; $\mathrm{i}=\mathrm{C} 2$-deficient patient.



FIG. 4 - Bactericidal action (plating technique) with $10 \%$ normal serum (ם), 10\% normal serum inactivated at $56^{\circ} \mathrm{C}$ for $30 \mathrm{~min}(\mathrm{O}), 10 \%$ serum from patient no. 1 with active rhinoscleroma ( $\square$ ), and PBS control without serum $(0)$. 
and our findings with hypogammaglobulinaemic and C2-deficient sera suggest that this is mediated mainly by the classical complement pathway. The wide range of ${ }^{14} \mathrm{C}$ release seen with sera from different normal subjects, particularly at low concentrations, is probably due to the variable serum concentrations of antibody to K. rhinoscleromatis or Klebsiella spp. (Michael, Whitby and Landy, 1962). Most normal subjects have a low titre of antibody to $K$. rhinoscleromatis when this is tested by a fluorescent technique for specific IgG on the surface of the organism (unpublished observations). In this context, it is interesting that serum from the hypogammaglobulinaemic patient on treatment with human IgG immunoglobulin showed a relatively greater release of isotope than that of the untreated virtually agammaglobulinaemic patient, when tested at low concentration (fig. 1). This suggests that specific antibody and the classical pathway are crucial in initiating cell-wall damage. Patients with severe hypogammaglobulinaemia probably have a little circulating IgG antibody to Klebsiella spp. although this may be difficult to demonstrate. This could partly explain why significant release of isotope was seen only at relatively high concentrations of serum from a severely hypogammaglobulinaemic patient (fig. 3). However, the pattern of this response, with a rapid rise in isotope release between serum concentrations of 30 and $40 \%$ suggests amplification by the alternative complement pathway. Patients with hypogammaglobulinaemia usually have raised serum levels of factor B (Nakajima, Nihei and Hyodo, 1978) which might account for this phenomenon.

Although direct comparison between our standard bactericidal assay by the plating technique and the ${ }^{14} \mathrm{C}$ release assay cannot be made, the latter probably does represent bacterial cell-wall damage. The release of ${ }^{14} \mathrm{C}$ is probably the result of the formation of complementdependent holes in the membrane. These holes can be seen by electronmicroscopy when $K$. rhinoscleromatis is exposed to normal fresh serum ( $\mathrm{R}$. Dourmashkin, unpublished).

Some bacteria are able to activate the alternative complement pathway directly without involving the classical pathway (Schreiber et al., 1979). Schenkein and Ruddy (1981) have also shown that IgG antibody is involved in activation of the alternative pathway by zymosan. However, neither of these mechanisms seems to operate in the release of isotope from $K$. rhinoscleromatis because of the negative results with $\mathrm{C} 2$-deficient serum.

The killing of $K$. rhinoscleromatis is similar to that described for Shigella by Reed and Albright (1974). They found that the killing of various strains of Shigella depended on activation of the classical pathway by specific antibody, with amplification by the alternative pathway.

Serum from the patient with active rhinoscleroma gave a normal response in the ${ }^{14} \mathrm{C}$ release assay when the concentration of serum was below $40 \%$. The subnormal response with higher concentrations of serum may be similar to that observed by Krasilnikov et al. (1974) because they were using serum concentrations of about $50 \%$ in their bactericidal assay. The reason for the inhibition at high serum concentrations is not known but may be due to a blocking effect by high concentrations of specific antibody. However, this is unlikely to be of importance in vivo because the concentration of serum proteins at mucosal surfaces can be very low.

The question still remains why patients with rhinoscleroma develop granuloma and how $K$. rhinoscleromatis escapes from the bactericidal effects of antibody and complement before being phagocytosed by cells in the nasal mucosa. Our findings indicate that, to answer this question, attention should be directed to the micro-environment of the nasopharynx.

We are most grateful for advice and technical help from Mr D. J. Frost of Charing Cross Hospital and the staff of the Department of Microbiology at Northwick Park Hospital. We also thank Mr D. K. Maddan and Mr N. B. Holden for allowing us to study their patients.

\section{REFERENCES}

Krasilnikov, A. P., Izraitel, N. A. and Shimanovich, S. V. 1974. Immune inhibition of bactericidal activity of sera. Report 1 . Bactericidal activity of the sera of healthy persons and those suffering from scleroma and its inhibition by specific antibodies. Zh. Mikrobiol. Epidem. Immunobiol., (1), 50 (in Russian).

Martin, A. AND LaChMANN, P. J. 1977. Haemolytic assays in agarose plates for components of 
the classical complement pathway: interference by the alternative pathway. Clin. exp. Immun., 27, 13.

Michael, J. G., Whitby, J. L. AND Landy, M. 1962. Studies on natural antibodies to gram-negative bacteria. J. exp. Med., 115, 131.

MuzyKa, M. M. And Gubina, K. M. 1972. Problems of the epidemiology of scleroma. Report No. 2. Some aspects of the problem of endemic focus formation. J. Hyg. Epidem. Microbiol. Immun., 16, 8.

Nakajima, S., NiheI, K. and Hyodo, Y. 1978. C3 activator in agammaglobulinemia. Int. Archs Allergy appl. Immun., 56, 563.

Reed, W. P. and Albright, E. L. 1974. Serum factors responsible for killing of Shigella. Immunology, 26, 205.

SCHENKEIN, H. A. AND RUDDY, S. 1981. The role of immunoglobulins in alternative complement pathway activation by zymosan. 1. Human IgG with specificity for zymosan enhances alternative pathway activation for zymosan. J. Immun., 126, 7.

Schreiber, R. D., Morrison, D. C., Podack, E. R. and Muller-Eberhard, H. J. 1979. Bactericidal activity of the alternative complement pathway generated from 11 isolated plasma proteins. J. exp. Med., 149, 870. 